700 horse-power, which give the ship a cruising speed of about 80 m.p.h. In length she is $803 \mathrm{ft}$.slightly less than the Hindenburg-but her hydrogen capacity of $7,062,000$ cub. ft. is fully 25 per cent greater.

\section{Iron Age Settlements in Wiltshire}

THE investigations by the Prehistoric Society of iron age sites near Salisbury have completed for the time being the examination of the settlement at Odstock, which began on June 12 under the direction of Mr. C. W. Phillips, honorary secretary of the Society. About half of the six-acre site has been dug ; and the remainder will be examined next year. The settlement is dated at about 200 B.c., and, as anticipated, was found to have been occupied by a small agricultural community, growing wheat, oats, barley, peas and beans, though traces of wheat only have been discovered. Apparently they farmed on an extensive scale. As much as fifty tons of grain was stored in a single season. Light is thrown on their methods in the report of the recent investigation (The Times, Sept. 6). Many pits for the bulk storage of grain were found within the settlement enclosure, but as storage in damp conditions would encourage the grain to sprout, it was first toasted in large ovens before being placed in the pits. Remains of ovens used for ordinary cookery have also been found, as well as quantities of pottery, iron knives, bone implements, etc. There is evidence that among the domestic animals were pigs, cows and goats, and a large number of horses of a small type. Some time after the first occupation, the settlement was surrounded by an enclosing bank and ditch, which were in no sense a fortification. Within this enclosure, in addition to the pits already mentioned, were a large house, a timber structure forty-five feet in diameter with an external veranda, a second, which was thirty feet in diameter, and a number of other timbered erections.

IF the inference as to the character and purpose of the fragments of pottery from the pits is well founded, and they are the remains of ovens which had been used for drying corn, this is the earliest link in a chain of evidence for a practice which can then be traced in Britain from about 200 B.c. down to modern times. In Antiquity of September, Dr. Cecil Curwen refers to the practice of drying corn in kilns in the island of Lewis, comparing the kilns with the corndrying furnaces found in some Romano-British settlements in southern Britain. Mr. O. G. S. Crawford in a note quotes evidence for the practice in the west back to at least the sixth century of our era; while Dr. Curwen, adding that the kilns seem to have been a product of Roman culture in western Europe, states that, so far as he was then aware, they did not occur in Britain before the latter part of the Roman period. The evidence from the Wiltshire settlement is thus of considerable interest as a possible instance, considerably earlier in date and not of Roman origin, of a practice with a prolonged history of cultural continuity.

\section{Prehistoric Scottish Temple}

Further progress is reported in the excavation of the prehistoric 'temple' at Clydebank, Dumbartonshire, of which Mr. Ludovic Mann is in charge. The central area of the site, in which are a large number of inhumed and cremated interments of the stone and bronze ages, is estimated to have a diameter of six hundred feet. A recent discovery, reported in The Times of September 19, is that of the remains of a circular walled enclosure, 43 feet in diameter, at a distance of $219 \frac{1}{4 t}$. from the main centre, which is now in course of being uncovered. In the walling to the north-west has been found a large rectangular stone. In contact with this was a fallen pillar-stone. This seems to have formed part of an altar-like structure. The pillar-stone had been shaped, and on cleaning showed traces of what are described as serpentine devices in black and red pigments-a discovery which, if confirmed by further examination, appears to be unique in British archæology. At a distance of $55 \mathrm{ft}$. from the centre of this stone ring, and on the same radius as the stone and pillar, was another large fallen upright stone. Many of the finds on this site, which include five different types of pottery, are said to be unique in character and technique. A large number of socket holes have been discovered, which contain decayed and carbonized wood, apparently largely of oak. The 'temple' seems to have consisted to a great extent of earthworks, of which the layout is indicated by the postholes along the margins. Traces of a circle of nineteen large equidistantly set monoliths have been detected at a distance of $129 \mathrm{ft}$. radius from the main centre. It is evident that this site is of considerable importance and complexity, and that careful excavation and planning will be necessary before its true character and purpose can be determined.

\section{Economic Use of Water-Power}

UNTIL recently, engineers considered that when both water- and fuel-power were available, then it was best to develop all the water-power first and then use steam as an auxiliary source of power. In designing many recent power stations this procedure has almost been reversed. The steam station is built first, the overhead costs being much cheaper; then when the load gets large and it would otherwise be necessary to provide reserve generators and equipment to take the main load, a beginning is made with the water-power station, which is mainly used to help with the peak load, and so avoids the necessity of purchasing reserve generators. In the preliminary report published in 1934 of the National Resources Board, set up by the United States Government, it is stated that "the great technical advantage of waterpower plants is that they can be turned on for a few hours' work and then turned off again without much loss". In the present technical regime, their function is mainly that of a supplementary source, used to carry peak loads for brief periods. During the rest of the time the load is carried by the more economical fuel burners. In the August number of the $B E A M A$ journal, H. E. M. Kensit points out that quite small water-power stations possessing good 